\title{
Strategi Pembina Galanggang Lubuk Aro dalam Pembinaan Keagamaan Islam Remaja
}

\author{
Ilman Suhdi ${ }^{1}$, Murniyetti ${ }^{2}$ \\ ${ }^{12}$ Fakultas Ilmu Sosial, Universitas Negeri Padang, Indonesia \\ *Corresponding author, e-mail: ilmanzuhdi90@gmail.com
}

\begin{abstract}
This study aims to determine the Strategy of Guiding Troubled in Islamic Religious Guidance for Teenagers in North Padang Mantinggi Village, Rao District, Pasaman Regency. This research is a type of field research using qualitative methods. Sources of data were taken from three informants consisting of coaches of trouble, five parents of teenagers, and fifteen members of teenagers using purposive sampling technique. Research data were taken through in-depth interviews with all informants. The results showed that the Guidance Strategy for Guidance in Islamic religious development for adolescents in Padang Mantinggi Utara Village, Rao District, Pasaman Regency, was by carrying out positive activities favored by teenagers, such as soccer and pencak silat training for teenage boys, marawis training. or tambourine and rhythm training for teenage girls. So that with positive activities it will be easier to direct teenagers to explore religious issues by participating in regular recitations in the hope that teenagers can have better knowledge of the Islamic religion.
\end{abstract}

Keywords: Strategy, Development, Islamic Religion, Youth

This is an open access article distributed under the Creative Commons 4.0 Attribution License, which permit unrestricted use, distribution, and reproduction in any medium, provided the original work is properly cited. C2018 by author.

\section{Pendahuluan}

Perbuatan remaja yang sering meresahkan masyarakat seperti menghisap lem, minumminuman keras yang memabukkan sehingga memicu perkelahian, berjudi, mencuri, dan yang paling parah yaitu penyalahgunaan narkoba. Hal ini menjadi alasan perlunya kegiatan pembinaan pada remaja dengan mencari strategi yang tepat untuk mengubah perilaku remaja yang sering melakukan perbuatan negatif dibutuhkan suatu strategi yang dapat mengarahkan remaja pada perbuatan yang baik.

Menurut Pupuh \& Sobri Pengertian strategi dari segi bahasa diartikan sebagai suatu siasat, kiat, taktik, trik, atau cara dalam bertindak untuk mencapai tujuan yang telah ditentukan (Barlian, 2013: 242). Pemilihan strategi yang tepat diperlukan untuk memudahkan kegiatan pembinaan pada remaja sehingga dengan strategi yang digunakan dalam pembinaan tersebut dapat menjadi penyokong yang kuat agar pembinaan pada remaja dapat berjalan dengan lancar. Strategi menurut Nanang Fattah \& H. Mohammad Ali mendefinisikan sebagai pemikiran secara konseptual, realistis dan komprehensif tentang langkah-langkah yang diperlukan untuk mencapai tujuan dan sasaran yang telah ditetapkan (Arifin, 2017: 118).

Strategi juga akan berjalan lancar jika pelaksanaannya sesuai dengan rencana yang disusun dengan rapi dan terorganisir dengan baik dengan memanfaatkan keunggulan dari kegiatan yang digunakan pada saat pembinaan. Adapun menurut Cravens, strategi adalah rencana yang disatukan dan terintegrasi menghubungkan keunggulan strategi organisasi dan dicapai melalui pelaksanaan yang tepat oleh organisasi. Menurut Aliminsyah dan Pandji mengartikan bahwa strategi adalah wujud rencana yang terarah untuk memperoleh hasil yang maksimal (Kholis, 2014: 5). 
Pembinaan berasal dari kata bahasa arab "bana" yang berarti membina, membangun, mendirikan. Menurut kamus besar Indonesia, pembinaan adalah suatu usaha tindakan dan kegiatan yang dilakukan secara berdaya guna dan berhasil guna untuk memperoleh hasil yang baik (Manan, 2017: 52). Pembinaan keagamaan perlu dilakukan mengingat remaja merupakan generasi yang akan menentukan kemajuan suatu daerah, apabila remaja dekat dan cinta kepada ajaran agamanya maka akan membuat keadaan masyarakat yang aman dan damai, tetapi apabila remaja jauh dari ajaran agama tentu akan menimbulkan masalah akhlak dan moral di lingkungannya. Pembinaan adalah proses perbuatan, pembaharuan penyempurnaan, usaha tindakan, dan kegiatan yang dilakukan secara terus menerus untuk memperoleh hasil yang lebih baik (Hadiawati, 2008: 19).

Sedangkan menurut Maolani pembinaan didefinisikan sebagai: Upaya pendidikan baik formal maupun nonformal yang dilaksanakan secara sadar, berencana, terarah dan bertanggung jawab dalam rangka menumbuhkan, membimbing dan mengembangkan dasardasar kepribadian yang seimbang, utuh dan selaras pengetahuan dan keterampilan sesuai dengan bakat serta kemampuan-kemampuannya sebagai bekal untuk selanjutnya atas prakarsa sendiri untuk menambah, meningkatkan dan mengembangkan dirinya, sesamanya maupun lingkungannya kearah tercapainya martabat, mutu dan kemampuan manusiawi yang optimal dan pribadi mandiri (Manan, 2017: 52).

Pembinaan keagamaan merupakan perihal yang berarti dalam kehidupan yang kondisinya masih mencemaskan. Terlebih pada saat ini remaja memakai media sosial yang sangat gampang untuk diakses. Remaja juga belum mampu memilah serta memilah data serta kontenkonten yang tidak baik, setelah itu akibat dari media social waktu remaja terbuang percuma, sebab bermain media sosial sehingga waktu buat mengamalkan ajaran agama Islam jadi terabaikan semacam sholat serta ibadah-ibadah yang lain. Pembinaan menurut (Masdar Helmi : 1973) adalah segala hal usaha, ikhtiar dan kegiatan yang berhubungan dengan perencanaan dan pengorganisasian serta pengendalian segala sesuatu secara teratur dan terarah (Heriyanti \& Zikri, 2019: 66).

Kondisi remaja yang sering melakukan pelanggaran tidak terlepas dari kondisi remaja tersebut apabila remaja itu diperhatikan dengan baik maka remaja akan menunjukkan perilaku yang baik pula karena mereka merasa diperhatikan. Menurut Sri Rumini \& Siti Sundari (2004: 53) masa remaja adalah peralihan dari masa anak dengan masa dewasa yang mengalami perkembangan semua aspek / fungsi untuk memasuki masa dewasa. Masa remaja berlangsung antara umur 12 tahun sampai dengan 21 tahun bagi wanita dan 13 tahun sampai dengan 22 tahun bagi pria (Surbakti, 2017: 30).

Remaja juga sedang dalam mencari identitas diri dan ingin diakui sebagai komponen masyarakat sehingga remaja sangat mudah terpengaruh dengan kehidupan dengan temantemannya. Menurut Zakiah Darajat (1990: 23) remaja adalah: Masa peralihan di antara masa kanak-kanak dan dewasa. Dalam masa ini anak mengalami masa pertumbuhan dan masa perkembangan fisiknya maupun perkembangan psikisnya. Mereka bukanlah anak-anak baik bentuk badan ataupun cara berpikir atau bertindak, tetapi bukan pula orang dewasa yang telah matang (Surbakti, 2017: 30).

Sedangkan menurut Santrock (2003: 26) bahwa remaja (adolescence) diartikan sebagai masa perkembangan transisi antara masa anak dan masa dewasa yang mencakup perubahan biologis, kognitif, dan sosial-emosional. Batasan usia remaja yang umum digunakan oleh para ahli adalah antara 12 hingga 21 tahun (Surbakti, 2017: 30). 
Remaja membutuhkan dukungan dari lingkungan. Dukungan sosial yang diterima remaja dari lingkungan, baik berupa dorongan semangat, perhatian, penghargaan, bantuan dan kasih sayang membuat remaja menganggap bahwa dirinya dicintai, diperhatikan, dan dihargai oleh orang lain. Jika individu diterima dan dihargai secara positif, maka individu tersebut cenderung mengembangkan sikap positif terhadap dirinya sendiri dan lebih menerima dan menghargai dirinya sendiri. Sehingga remaja mampu hidup mandiri ditengah-tengah masyarakat luas secara harmonis (Kumalasari \& Nur Ahyani, 2012: 22).

Dalam perspektif dakwah, kalangan remaja merupakan salah satu kelompok mad'u yaitu kelompok yang sedang menuntut ajaran agama, yang memiliki potensi besar dalam pembinaan umat. Rusaknya akhlak remaja tentu akan memberi pengaruh nyata pada kerusakan masyarakat dan dapat memberikan dampak negatif pada ketentraman hidup bahkan akan menghilangkan ketentraman dan ketertiban masyarakat. Di sisi lain, permasalahan remaja harus dipandang sebagai bagian dari masalah pembangunan nasional sebab remaja sebagai generasi penerus bangsa akan menentukan gerak pembangunan bangsa ke depan dan menentukan ke arah mana kehidupan suatu bangsa akan dibawa. Justru itu, problema dakwah di kalangan remaja merupakan salah satu prioritas utama untuk ditangani bersama, baik oleh para juru dakwah, guru, orang tua, bahkan seluruh umat Islam. Hal ini sesuai dengan tujuan dakwah untuk mewujudkan masyarakat yang Islami serta demi masa depan Islam yang rahmatan li al-alamin (Nuwairah, 2015: 1).

Setelah peneliti melakukan observasi di desa Padang Mantinggi Utara Kecamatan Rao Kabupaten Pasaman pada tanggal 03 Desember 2020. Terkait isu yang penulis angkat dalam penelitian ini, sebelum adanya kegiatan pembinaan, ditemukan banyak remaja belum mampu melaksanakan tata cara bersuci, tata cara ibadah shalat dan tata cara penyelenggaraan jenazah dengan baik dan benar. Perilaku remaja yang menyimpang dari nilai-nilai ajaran Islam seperti menghisap lem, minum-minuman keras yang memabukkan sehingga memicu perkelahian yang sering terjadi ketika ada acara, berjudi, mencuri, dan yang paling parah yaitu penyalahgunaan narkoba. Kondisi remaja masih banyak yang melakukan penyimpangan disebabkan karena rendahnya tingkat pendidikan, putus sekolah, malas belajar, dipengaruhi teman sepergaulan dan rendahnya kesadaran sebagai seorang muslim. Hal itu disebabkan karena mereka belum mengamalkan ajaran agama secara baik.

Melihat kondisi remaja yang meresahkan masyarakat tersebut akhirnya terbentuklah Galau (Galanggang Lubuk Aro), yang diprakarsai oleh bapak Yusnil Marta untuk melakukan pembinaan. Adapun kegiatan pembinaan yang dilakukan terhadap remaja yaitu dengan mengadakan kegiatan positif yang disukai oleh remaja seperti mendirikan kegiatan pencak silat, pengajian rutin, pelatihan sepak bola, pelatihan irama, pelatihan marawis atau rebana. Kegiatan pencak silat hanya dilakukan oleh remaja laki-laki yang dilaksanakan pada sore hari atau malam hari di perkebunan. Hal ini dimanfaatkan sebagai strategi untuk mengajarkan kepada remaja tata cara bersuci, tata cara ibadah shalat dan tata cara penyelenggaraan jenazah. Pengajian rutin dilaksanakan pada malam hari sesudah shalat isya di gedung Madrasah Diniyyah Awaliyah (MDA). Pengajian rutin ini dilakukan untuk menambah wawasan remaja mengenai ilmu agama islam.

Pelatihan sepak bola diadakan pada sore hari dikarenakan ini menjadi hobi yang sangat diminati remaja laki-laki. Adapun kegiatannya yaitu latihan sepak bola, mengikuti sparing ke daerah lain, mengikuti Open Turnamen (kompetisi sepak bola). Melalui kegiatan ini diharapkan remaja laki-laki semangat dalam mengikuti kegiatan pengajian rutin. Pelatihan irama diadakan pada malam hari sesudah shalat isya dengan mengundang guru yang sudah berpengalaman dengan harapan remaja yang mengikuti pelatihan irama dapat mengembangkan bakatnya. 
Pelatihan marawis atau rebana diadakan pada malam hari sesudah shalat isya, kegiatan ini sangat di minati remaja perempuan. Kegiatan ini dipandu oleh bapak Alex. Melalui kegiatan ini diharapkan remaja perempuan semangat dalam mengikuti kegiatan pengajian rutin.

Jika dianalisis fenomena yang terjadi maka akan menimbulkan pertanyaan yaitu bagaimana Strategi Pembina Galau dalam Pembinaan Keagamaan Islam Pada Remaja Di Desa Padang Mantinggi Utara Kecamatan Rao Kabupaten Pasaman? apa faktor penghambat Strategi Pembina Galau dalam Pembinaan Keagamaan Islam Pada Remaja? dan apa manfaat dari Pembinaan Keagamaan Islam Pada Remaja?

\section{Metode}

Penelitian ini merupakan jenis penelitian lapangan (field research) dengan menggunakan metode kualitatif. Denzin dan Lincoln menyatakan bahwa penelitian kualitatif adalah penelitian yang menggunakan latar belakang alamiah, dengan maksud menafsirkan fenomena yang terjadi dan dilakukan dengan jalan melibatkan berbagai metode yang ada dalam penelitian kualitatif. Metode yang biasanya dimanfaatkan adalah wawancara, pengamatan, dan pemanfaatan dokumen (J Moleong, 2013: 5). Sumber data diambil dari tiga orang informan yang terdiri atas Pembina Galau, lima orang tua remaja, dan lima belas anggota remaja menggunakan teknik purposive sampling. Dalam penelitian ini, teknik pengumpulan data dilakukan melalui wawancara secara mendalam kepada informan dan studi dokumentasi. Data dianalisis dengan cara mereduksi data, menyajikan data dan penarikan kesimpulan

\section{Hasil dan Pembahasan}

\section{Sejarah Galau (Galanggang Lubuk Aro)}

Berdasarkan wawancara yang telah peneliti lakukan pada tanggal 03 Oktober 2021 dengan Pembina Galau yaitu Bapak yusnil Marta didapati sejarah galau sebagai berikut: Berdirinya atau terciptanya pemikiran kami untuk mengasah dan mengasuh anak-anak remaja itu mulai dari tahun 2006. Karena di waktu itu keadaan anak-anak kita itu sudah jauh dari pada apa yang kita harapkan masalah agama, dan terbentuklah namanya Galau atau Galanggang Lubuk Aro dan kegiatan-kegiatan apapun yang dilaksanakan dan diikuti oleh anak-anak remaja itu tetap nama grupnya Galau, karena semua dilaksanakan di jorong VI Lubuk Aro, dan sampai sekarangpun Alhamdulillah kegiatan itu masih terlaksana dan sudah beberapa tahun ini namanya tetap galau dan tidak bisa di tukar dengan nama yang lain". Dari kutipan wawancara diatas dapat disimpulkan bahwa kegiatan pembinaan remaja sudah dimulai sejak tahun 2006 dikarenakan kondisi perilaku anak-anak remaja yang jauh dari ajaran agama Islam. Sehingga bapak Yusnil Marta membuat sebuah organisasi yang bernama Galau "Galanggang Lubuk Aro".

\section{Struktur Organisasi Galau (Galanggang Lubuk Aro)}

a. Pembina Galau

Pembina Galau adalah bapak Yusnil Marta, umur beliau 46 tahun dengan pendidikan terahir yaitu pesantren Maramais. Pekerjaan beliau adalah wiraswasta. Beliau menjadi Pembina galau sejak tahun 2006 dan masih aktif sampai sekarang.

b. Penasehat Galau

Penasehat pertama Galau adalah bapak Aldi, umur beliau 38 tahun pendidikan terakhir SMA, Pekerjaan beliau yaitu petani. Beliau masih aktif sampai sekarang untuk membantu dalam melakukan kegiatan pembinaan terhadap remaja Galau. Penasehat yang kedua adalah bapak Dedi Irawan umur beliau 36 Tahun Pendidikan terakhir SMP. Pekerjaan beliau adalah petani. Beliau masih aktif sampai sekarang untuk membantu dalam melakukan kegiatan pembinaan terhadap remaja. 
c. Ketua Galau

Ketua Galau adalah Ibrahim, umur beliau 27 tahun pendidikan terakhir yaitu SMA, kesehariannya ialah petani. Beliau masih aktif sampai sekarang untuk mengkoordinir anggota Galau dalam melakukan kegiatan pembinaan terhadap remaja.

d. Bendahara

Bendahara Galau adalah Zultia Reni, umurnya 21 tahun, pendidikan mahasiswi IAIN Bukit Tinggi, beliau masih aktif sampai sekarang sebgai bendahara Galau.

e. Anggota Galau

Anggota Galau terdiri dari pelajar, mahasiswa, pengangguran, pekebun dan petani. Jumlah dari anggota Galau yaitu 94 orang, terdiri dari 64 laki-laki dan 30 perempuan.

3. Visi Dan Misi Galau (Galanggang Lubuk Aro)

Visi dari Galau yaitu Organisasi Galau berorientasi pada pembinaan akhlak yang baik dengan akidah yang benar. Itu visi yang sebenarnya dilaksanakan galau sejak awal sampai sekarang. Sedangkan Misi dari Galau ialah mengadakan dan melaksanakan kegiatan pembinaan yang memiliki nilai positif. mengusahakan kerja yang ikhlas, sabar dengan semangat fi Sabilillah, menjalankan serta menyukseskan kegiatan Galau.

4. Sarana Dan Prasarana Galau (Galanggang Lubuk Aro)

Adapun sarana dan prasarana yang dipakai oleh galau adalah sebagai berikut:

a) Gedung MDA (Madrasah Diniyyah Awwaliyah).

b) Fasilitas Masjid Nurul Iman (pengeras suara, Al-Qur'an).

c) Lapangan Sepak Bola.

d) Peralatan Marawis dan peralatan Rebana

e) Kebun Tempat pelatihan pencak silat.

Sarana dan Prasarana yang dipakai oleh galau seperti gedung MDA, Masjid dan lapangan sepak bola bukanlah milik Galau, melainkan itu adalah milik orang lain atau masyarakat yang dipakai setelah minta izin kepada pihak tertentu yang berkaitan dengan sarana tersebut. Sarana dan prasarana yang dimiliki Galau sangat minim karena masih banyak kekurangannya.

\section{Program Kegiatan Galau (Galanggang Lubuk Aro)}

Nama program dan jadwal kegiatan dari masing-masing anggota Galau dapat dilihat pada tabel di bawah ini:

\begin{tabular}{|l|l|l|l|l|}
\hline No & Nama Kegiatan & Jadwal Siang & Jadwal Malam & Guru \\
\hline 1. & Pencak Silat & & Selasa \& Jumat & Bpk.Yusnil \\
\hline 2. & Sepak Bola & Rabu \& Minggu & & Bpk.Alex \\
\hline 3. & Pengajian Rutin PA & & Rabu \& Minggu & Bpk.Yusnil \\
\hline 4. & Pengajian Rutin PI & & Senin \& Kamis & Bpk.Yusnil \\
\hline 5. & Pelatihan Irama & & Selasa \& Sabtu & Bpk.Qosim \\
\hline 6. & Pelatihan Marawis & & Rabu \& Jumat & Bpk.Alex \\
\hline
\end{tabular}

Dari tabel diatas dapat diketahui bahwa :Kegiatan pencak silat dilaksanakan pada malam selasa dan jumat dengan guru bapak Yusnil Marta, Kegiatan sepak bola dilaksanakan pada hari rabu dan minggu dengan guru bapak Alex, Kegiatan pengajian rutin putra dilaksanakan pada malam rabu dan minggu dengan guru bapak Yusnil Marta, Kegiatan pengajian rutin putri dilaksanakan pada malam senin dan kamis 
dengan guru bapak Alex, Kegiatan pelatihan irama dilaksanakan pada malam selasa dan sabtu dengan guru bapak Qosim dan Kegiatan pelatihan marawis atau rebana dilaksanakan pada malam rabu dan jumat dengan guru bapak Alex

\section{Pembahasan.}

\section{A. Strategi Pembina Galau (Galanggang Lubuk Aro) dalam Pembinaan Keagamaan Islam Pada Remaja di Desa Padang Mantinggi Utara Kecamatan Rao Kabupaten Pasaman}

Untuk mengetahui strategi yang dilakukan Pembina Galanggang Lubuk Aro dalam pembinaan keagamaan islam pada remaja di Desa Padang Mantinggi Utara Kecamatan Rao Kabupaten Pasaman peneliti melakukan observasi ke lokasi penelitian pada tanggal 25 September 2021, peneliti menemukan bahwa Strategi Pembina Galau dalam Pembinaan Keagamaan Islam pada Remaja di Desa Padang Mantinggi Utara Kecamatan Rao Kabupaten Pasaman yaitu: Melakukan kegiatan-kegiatan positif yang disukai oleh remaja, seperti pelatihan sepak bola dan pencak silat untuk remaja laki-laki. Pelatihan marawis atau rebana untuk remaja perempuan. Sehingga dengan adanya kegiatan yang positif akan lebih mudah mengarahkan remaja untuk mendalami masalah agama. Setelah hobi remaja ini disalurkan maka Pembina Galau membuat kegiatan lain seperti pengajian rutin dan pelatihan irama dengan harapan remaja dapat memiliki pengetahuan agama islam serta pribadi yang baik.Adapun kegiatan positif yang dilaksanakan oleh Galau sebagai berikut:

\section{Pencak Silat}

Kegiatan pencak silat dilaksanakan di perkebunan pada malam hari, namun apabila ada kendala pada malam hari maka akan diganti pada sore hari. Kegiatan ini hanya diikuti oleh remaja laki-laki. Jadwal latihan pencak silat yaitu pada malam selasa dan malam jumat. Adapun yang akan membina kegiatan ini adalah Pembina Galau yaitu bapak Yusnil Marta.

Rangkaian kegiatannya dimulai dengan berdoa bersama yang dipimpin oleh ketua Galau, memohon perlindungan kepada Allah SWT dengan membaca dua kalimat syahadat, shalawat kepada nabi Muhammad SAW, membaca surah Al-Fatihah, An-nas, Al-Falaq, Al-Ikhlas, kemudian menyampaikan hajat kepada Allah SWT, meminta perlindungan dan dijauhkan dari bahaya serta mendapatkan keberkahan dari ilmu yang dipelajari, terakhir ditutup dengan membaca ayat kursi serta bersalaman kepada guru dan anggota lainnya. Selanjutnya para anggota memulai dengan latihan fisik yang akan di pimpin oleh guru. Setelah latihan selesai, maka semua anggota akan duduk bersama, melalui metode ceramah, praktek, diskusi dan tanya jawab, guru akan menerangkan materi dan memberikan contoh yang mudah dimengerti.

Adapun materi yang disampaikan seperti tata cara bersuci, tata cara ibadah shalat dan tata cara penyelenggaraan jenazah. Setelah pemberian materi, guru akan memberikan contoh prakteknya supaya lebih mudah dipahami. Seperti tata cara bersuci, guru akan membawa anggota ke sungai yang dekat dari lokasi pelatihan. Apabila ada yang tidak dipahami, maka anggota dibolehkan untuk menanyakannya kepada guru tersebut.

Untuk memperkuat temuan ini, peneliti melakukan wawancara dengan Pembina Galau pada tanggal 28 Oktober 2021.

Menurut bapak Yusnil Marta yaitu cara kita mengajarkan masalah keagamaan itu dalam pencak silat, yang pertama yaitu di ambil waktunya malam hari, pencak silat ini ada dua kali dalam seminggu dan dua kali di laksanakan pengajian pengajian baik itu wudhu, istinja, masalah thaharah yang lain dan juga masalah jenazah itu dua malam juga diambil waktunya dalam seminggu, dan cara kami mengajarkannya itu langsung dipraktekkan kalau itu misalannya wudhu dan istinja setelah kami mengajarkan materinya, kami langsung dipraktekkan ke sungai yang dekat dengan lokasi kami, begitu juga dengan praktek masalah jenazah atau penyelesaian mayit itu, setelah materi-materinya diberikan kepada anak-anak itu juga memakai media baik itu koran misalannya atau boneka-boneka untuk mempraktekkan langsung kepada anak-anak tersebut dan yang paling utamanya apabila hal tersebut tidak dikuasai anak-anak anggota pencak silat, secara pelan-pelan atau berangsur- 
angsur memberikan sanksi kepada anak-anak tersebut untuk tidak ikut lagi dalam dunia pencak silat begitu.

Untuk menguatkan penemuan ini, peneliti juga melakukan wawancara tertulis pada tanggal 18 Oktober 2021 terhadap beberapa anggota yang mengikuti kegiatan pencak silat. Sebagai berikut:

Menurut Ahmad Fauzi yaitu diadakan pengajian khusus tiap malam tertentu, untuk membahas masalah agama islam seperti istinja, wudhu, pengajian masalah Jenazah dan tanya jawab hukum islam. Menurut Aulia Fajri yaitu bapak Yusnil Marta mengajarkan materi tersebut dengan cara menjelaskan dan mempraktekkan terlebih dahulu kemudian langsung di praktekkan oleh murid-muridnya. Menurut Alfin Fauzan yaitu beliau akan memberikan contoh bagaimana tata tertibnya, lalu beliau akan menyuruh kita menghafal niat dan tata tertibnya yang sudah ditunjukkan beliau, dan jika sudah hafal lalu kita akan di tes oleh beliau.

Dari kutipan wawancara diatas dapat disimpulkan bahwa strategi yang dilakukan Pembina Galau dalam Pembinaan Keagamaan Islam pada remaja yang mengikuti kegiatan pencak silat yaitu menjelaskan materi dengan cara yang mudah dipahami, kemudian memberikan contoh prakteknya seperti berwudhu ke sungai yang dekat dengan lokasi pencak silat, dan guru juga memberikan hafalan seperti melaksanakan tata cara bersuci, tata cara ibadah shalat dan tata cara penyelenggaraan jenazah kepada anggota pencak silat.

\section{Pengkajian Rutin}

Pengajian rutin merupakan kegiatan yang dilaksanakan oleh remaja laki-laki dan remaja perempuan setelah shalat isya. Jadwal pengajian untuk remaja laki-laki adalah pada malam rabu dan malam minggu, sedangkan jadwal untuk remaja perempuan pada malam senin dan malam kamis. Adapun guru yang mengajar adalah bapak Yusnil Marta. Kegiatan ini dilaksanakan di gedung MDA (Madrasah Diniyyah Awwaliyah). Adapun materi yang disampaikan seperti belajar membaca Al-Qur'an, tata cara bersuci, tata cara ibadah shalat dan tata cara penyelenggaraan jenazah.

Rangkaian kegiatannya yaitu berdoa sebelum pelajaran dimulai, penyampaian materi oleh guru melalui ceramah, praktek dan tanya jawab. Guru akan membagi anggota menjadi beberapa kelompok, kemudian masing masing kelompok akan bersaing, apabila kelompoknya kalah maka tidak akan mendapatkan makanan dan jika kelompoknya menang maka akan mendapatkan hadiah berupa makanan yang sudah disiapkan sebelumnya. Di akhir pengajian guru akan memberikan pemberian tugas berupa hafalan mengenai materi yang telah diajarkan.

Untuk memperkuat temuan ini, peneliti melakukan wawancara dengan Pembina Galau pada tanggal 28 Oktober 2021.

Menurut bapak Yusnil Marta yaitu tata cara kita untuk mengajarkan materi materi yang akan disampaikan atau diajarkan kepada anak-anak pengajian yang usia anak-anak itu dari kelas 3 SD sampai kelas 1 SMP sederajat atau menjelang remaja itu juga diadakan dua malam dalam satu minggu, itu malam Minggu dan juga malam Kamis dan pelaksanaan itu ada di gedung MDA, kemudian pelaksanaannya juga memakai papan tulis atau juga materi-materi kita sampaikan juga semuanya baru kita melakukan praktek dengan anakanak tersebut baik itu mengenai istinja dan wudhu juga mengenai masalah jenazah, itu yang paling utamanya diberikan materi dan dihafalkan dulu kepada anak-anak itu dikuasai baca bacaannya dulu semuanya baru kita langsung kan kepada praktek baik itu istinja wudhu dan jenazahnya memakai media-media juga seperti media koran sebagai kain kafan dan juga boneka sebagai ganti mayitnya itu yang kami laksanakan".

Peneliti juga melakukan wawancara terhadap beberapa anggota yang mengikuti kegiatan pengajian rutin. Menurut Aisyah yang diajari bapak itu kami paham yang dijelaskannya mengenai berwudhu, istinja kemudian dipraktekkan secara berkelompok. Menurut Nazila yaitu caranya adalah belajar sambil mempraktekkan materi yang akan diajarkan. Menurut Fitran yaitu caranya bapak menjelaskan satu persatu tentang tata cara bersuci. 
Dari kutipan wawancara diatas dapat disimpulkan bahwa Strategi Pembina Galau Dalam Pembinaan Keagamaan Islam pada Remaja pada kegiatan pengajian rutin yaitu menjelaskan materi dan dihafalkan terlebih dahulu oleh anak-anak, kemudian setelah dikuasai bacaannya baru dilangsungkan kepada praktek secara berkelompok.

\section{Pelatihan Sepak Bola}

Pelatihan Sepak bola diadakan di sore hari, adapun jadwal latihannya yaitu pada hari rabu dan minggu. Kegiatan ini hanya diikuti oleh remaja laki-laki. Adapun rangkaian kegiatannya adalah latihan bersama, sparing ke tempat lain dan mengikuti Open Turnamen yaitu kompetisi sepak bola. Pelatih sepak bola bernama bapak Alex. Adapun honor yang diberikan yaitu sebanyak Rp 25.000 sekali latihan. Pada kegiatan ini peneliti tidak menemukan adanya pembinaan keagamaan islam, Kegiatan ini diadakan agar remaja lakilaki lebih semangat dalam mengikuti pengajian rutin untuk memperdalam ilmu agama islam

\section{Pelatihan Irama}

Kegiatan pelatihan irama dilaksanakan di Masjid Nurul Iman jorong VI Lubuk Aro. Kegiatan ini dilaksanakan sesudah shalat isya pada malam selasa dan malam sabtu. Remaja yang mengikuti kegiatan ini telah diseleksi terlebih dahulu, apabila remaja bisa membaca Al-Qur'an dengan makhraj huruf dan tajwid yang baik, maka akan diikutkan untuk pelatihan irama tersebut. Adapun guru yang melakukan pelatihan yaitu bapak Qosim, beliau merupakan seorang Qori. Untuk honor beliau diberikan setiap kali mengajar sebanyak Rp 60.000. Pada kegiatan ini peneliti tidak menemukan adanya pembinaan keagamaan islam, dengan kegiatan pelatihan ini diharapkan remaja dapat melatih dan mengeluarkan bakat terbaiknya dan rajin mengikuti pengajian rutin.

\section{Pelatihan Marawis atau Rebana}

Kegiatan pelatihan marawis dilakukan pada malam Rabu dan malam Jumat sesudah shalat isya. Adapun guru yang mengajar pelatihan marawis adalah bapak Alex, pelatihan ini sangat diminati oleh remaja putri, Adapun honor yang diberikan setiap kali mengajar yaitu sebanyak $\mathrm{Rp}$ 25.000. Pada kegiatan ini peneliti tidak menemukan adanya pembinaan keagamaan islam, dengan kegiatan ini diharapkan remaja putri lebih bersemangat untuk mengikuti pengajian rutin.

B. Faktor Pendukung Strategi Pembina Galau (Galanggang Lubuk Aro) dalam pembinaan keagamaan islam pada remaja di Desa Padang Mantinggi Utara kecamatan Rao Kabupaten Pasaman

Untuk menguatkan temuan ini peneliti melakukan wawancara dengan Pembina Galau pada tanggal 05 Oktober 2021. Menurut bapak Yusnil Marta faktor pendukung dari galau boleh dikatakan tidak ada, akan tetapi pendukung yang paling penuh yaitu semangat dari anak-anak ini dan juga beberapa kawan-kawan yang satu visi dan misi dengn kami supaya galau tidak berhenti di tengah jalan, jadi intinya faktor pendukung itu tidak ada dari luar cuma semangat dari anak-anak yang kami didik dan juga kawan-kawan itu saja yang kami pertahankan sampai saat ini.

Untuk menguatkan data ini, peneliti melakukan wawancara kepada beberapa orang tua dari anggota Galau. Menurut ibu Rohima yaitu saya selaku orang tua sangat mendukung kegiatan yang dilakukan Galau agar anak saya bisa mempelajari dan memahami masalah agama. Menurut ibuk Miskah yaitu Alasan saya adalah untuk membentuk pribadi yang islami yang berilmu dan pengetahuan sekaligus mengawasi anakanak saya di luar rumah. Menurut bapak Dedi yaitu alasannya saya adalah untuk mengurangi kenakalan anak-anak kami dan meningkatkan agama islami dan meringankan beban untuk mengawasi anak-anak saya. Jadi dapat disimpulkan bahwa faktor pendukung adalah sebagai berikut:

1. Adanya dukungan dari pihak orang tua remaja yang mengikuti kegiatan.

2. Semangat dari anggota remaja dan semangat dari kawan-kawan Pembina Galau yang satu visi dan misi untuk membina remaja. 
C. Faktor Penghambat Strategi Pembina Galau (Galanggang Lubuk Aro) Dalam Pembinaan Keagamaan Islam Pada Remaja Di Desa Padang Mantinggi Utara Kecamatan Rao Kabupaten Pasaman

Berdasarkan wawancara yang peneliti lakukan pada tanggal 03 Oktober 2021dengan Pembina Galau bapak Yusnil Marta yaitu kendala yang sangat fatal di hadapi semuanya menurut pendapat kami, susah untuk mencapai kemajuan itu atau keberhasilan itu tanpa diiringi dengan pendanaan, akan tetapi ketika pendanaan itu di beratkan dibebankan kepada anak tersebut apalagi orangtuanya, itulah susahnya masalah agama makanya inti kendala yang kami temui dan kami rasakan selama ini adalah tidak adanya support dana dari manapun atau itu dari pemerintahan atau dari orang-orang kaya istilahnya, yang akan membantu kami karena keadaan itu atau kegiatan itu tidak dipublikasikan. Faktor penghambat yang paling utama yaitu memfasilitasi anak-anak ini kalau misalnya di gelanggang bela diri yang seharusnya memakai kostum itu tidak ada, kalau misalnya bermain bola kaki juga boleh dikatakan tidak ada, jadi semuanya penghambat itu tidak bisa diceritakan karena kami tidak melibatkan pihak pemerintah dan juga instansi-instansi terkait dari pemerintahan yang paling rendah itu tidak ada, intinya faktor penghambat itu kami yang merasakan semuanya.

Jadi dapat disimpulkan bahwa faktor penghambat dari Strategi Pembina Galau dalam Pembinaan Keagamaan Islam pada Remaja di Desa Padang Mantinggi Utara Kecamatan Rao Kabupaten Pasaman yaitu:

a. Kurangnya sarana prasarana seperti kostum untuk sepak bola, baju seragam untuk pencak silat.

b. Kurangnya pendanaan karena anggota remaja Galau hanya membayar seadanya.

c. Remaja yang susah menguasai materi yang diajarkan ketika pelaksanaan kegiatan.

D. Solusi Dalam Mengatasi Faktor Penghambat Strategi Pembina Galau (Galanggang Lubuk Aro) Dalam Pembinaan Keagamaan Islam Pada Remaja Di Desa Padang Mantinggi Utara Kecamatan Rao Kabupaten Pasaman

Solusi Pembina Galau dalam mengatasi faktor penghambat dari Strategi Pembina Galau Dalam Pembinaan Keagamaan Islam Pada Remaja di Desa Padang Mantinggi Utara dapat ditemukan dalam kutipan wawancara dengan Pembina Galau pada tanggal 03 Oktober 2021 sebagai berikut:

1) Untuk mengatasi faktor penghambat sarana dan prasarana seperti kostum sepak bola dan baju seragam pencak silat peneliti menemukan bahwa boleh diganti dengan pakaian sehari-hari yang bisa digunakan untuk menjalankan kegiatan.

2) Untuk mengatasi masalah kurangnya pendanaan menurut bapak Yusnil Marta untuk mengatasi kendala-kendala tersebut kami ambil kebijakan untuk menghubungi kawankawan atau teman-teman kita yang searah dengan kita itu yang diberikan Allah kelebihan rezeki dan itulah yang kami surati kami suguhkan donator istilahnya untuk membantu kegiatan-kegiatan tersebut, karena apabila itu kami sampaikan kepada pihak pemerintahan rasa-rasanya sangat sulit untuk mendapatkan apa yang kami inginkan makanya kami mencari donatur yang orang-orangnya searah dengan kami.

3) Untuk mengatasi masalah remaja yang susah menguasai materi yang diajarkan peneliti menemukan bahwa banyak dari anggota yang memiliki waktu luang di malam hari akan mendatangi rumah Pembina Galau atau basecamp Galau untuk diasuh lagi. Kemudian diskusi akan berlangsung dimana anggota akan bertanya untuk memperdalam ilmu agamanya.

E. Manfaat Dari Strategi Pembina Galau (Galanggang Lubuk Aro) Dalam Pembinaan Keagamaan Islam Pada Remaja Di Desa Padang Mantinggi Utara Kecamatan Rao Kabupaten Pasaman

Untuk menemukan apakah ada perubahan yang terjadi pada remaja setelah pembinaan, peneliti melakukan wawancara dengan pembina Galau pada tanggal 03 Oktober 2021. Menurut bapak Yusnil Marta masalah perubahan yang terjadi kepada remaja terhadap anak bimbingan kami secara berangsur kami lihat sudah ada, yang biasa itu melakukan pekerjaan yang negatif seperti menghisap lem, ganja, atau pencurian dan lain sebagainya, itu secara berangsur sudah mereka rubah karena tetap kami pantau dan 
kami awasi sekalipun istilahnya tidak di hadapan kami karena banyak kawan-kawan kami tim pemeriksa istilahnya untuk mengawasi anak anak itu di luar dan mereka takut istilahnya untuk di sampaikan hal itu kepada kami. Alhamdulillah dengan pengawasan itu mereka sangat jauh berubah kepada yang baik.

Dari kutipan wawancara tersebut dapat disimpulkan bahwa anggota remaja yang telah mengikuti kegiatan Galau didapati perubahan kepada yang lebih baik, karena mereka tetap dipantau oleh kawan-kawan dari Pembina Galau dan dengan pantauan tersebut remaja takut untuk berbuat hal negatif.

\section{Simpulan}

Berdasarkan penelitian yang telah dilakukan melalui observasi wawancara dan dokumentasi peneliti menarik kesimpulan sebagai berikut: Strategi Pembina Galau dalam pembinaan keagamaan islam pada remaja di Desa Padang Mantinggi Utara kecamatan Rao Kabupaten Pasaman yaitu dengan cara melakukan kegiatan-kegiatan positif yang disukai oleh remaja, seperti pelatihan sepak bola dan pencak silat untuk remaja laki-laki, pelatihan marawis atau rebana dan pelatihan irama untuk remaja perempuan. Sehingga dengan adanya kegiatan yang positif akan lebih mudah mengarahkan remaja untuk mendalami masalah agama dengan ikut pengajian rutin dengan harapan remaja dapat memiliki pengetahuan agama islam yang lebih baik.

Faktor pendukung Strategi Pembina Galau dalam pembinaan keagamaan islam pada remaja di Desa Padang Mantinggi Utara kecamatan Rao Kabupaten Pasaman yaitu adanya dukungan dari pihak orang tua remaja yang mengikuti kegiatan dan semangat dari anggota remaja serta semangat dari kawan-kawan Pembina Galau yang satu visi dan misi untuk membina remaja.

Faktor penghambat Strategi Pembina Galau dalam pembinaan keagamaan islam pada remaja di Desa Padang Mantinggi Utara kecamatan Rao Kabupaten Pasaman yaitu kurangnya sarana prasarana seperti kostum untuk sepak bola dan baju seragam untuk pencak silat. Kurangnya pendanaan karena anggota remaja Galau hanya membayar seadanya. Remaja yang susah menguasai materi yang diajarkan. Untuk Peneliti selanjutnya diharapkan penelitian ini menjadi referensi dan membuat gambaran yang lebih baik terkait Strategi Pembinaan Keagamaan pada Remaja.

Manfaat dari strategi Pembina Galau dalam pembinaan keagamaan islam pada remaja di Desa Padang Mantinggi Utara kecamatan Rao Kabupaten Pasaman yaitu anggota remaja yang telah mengikuti kegiatan Galau didapati perubahan kepada yang lebih baik, karena mereka tetap dipantau oleh kawan-kawan dari Pembina Galau dan dengan pantauan tersebut remaja takut untuk berbuat hal negatif..

\section{Daftar Kepustakaan}

Arifin, A. (2017). Strategi Manajemen perubahan dalam meningkatkan disiplin diperguruan tinggi. EDUTECH ilmu pendidikan dan ilmu sosial, 3(1), 117-132.

Barlian, I. (2013). Begitu Pentingkah Strategi Belajar Mengajar Bagi Guru? Forum Sosial Jurusan Pendidikan Ilmu Pengetahuan Sosial Fakultas Keguruan Dan Ilmu Pendidikan Universitas Sriwijaya., 6(01), 241-246.

Hadiawati, L. (2008). Pembinaan Keagamaan Sebagai Upaya Meningkatkan Kesadaran Siswa Melaksanakan Ibadah Shalat (Penelitian Di kelas X dan XI SMK Plus QurrotaAyun Kecamatan Samarang Kabupaten Garut. " Jurnal Pendidikan UNIGA, 02(01), 18-25. 
Heriyanti, Y., \& Zikri, A. (2019). Pembinaan Dan Pengawasan Pemerintah Terhadap Penyelenggaraan Perumahan Dan Kawasan Permukiman Menurut Undang-Undang No 1 Tahun 2011 Tentang Perumahan Dan Kawasan Peermukiman. Jurnal ArTSip, 01(02), 6573 .

J Moleong, L. (2013). Metode Penelitian Kualitatif. Bandung: PT. Remaja Rosdakarya.

Kholis, N. (2014). Manajemen strategi pendidikan: (formulasi, implementasi dan pengawasan). Diambil dari http://digilib.uinsby.ac.id/19693/

Kumalasari, F., \& Nur Ahyani, L. (2012). Hubungan Antara Dukungan Sosial Dengan Penyesuaian Diri Remaja Di Panti Asuhan Latifah Nur Ahyani. Jurnal Psikologi Pitutur, 1(1), 21-31.

Manan, S. (2017). Pembinaan akhlak mulia melalui keteladanan dan pembiasaan. Jurnal Pendidikan Agama Islam-Ta'llim, 15(1), 49-65.

Nuwairah, N. (2015). Peran Keluarga dan Organisasi Remaja Masjid Dalam Dakwah Terhadap Remaja. Al-Hiwar, 3(6), 1-12.

Surbakti, K. (2017). Pengaruh Game Online Terhadap Remaja. Jurnal Curere, 01(01), 28-38. 